\title{
Scurvy with gastrointestinal bleeding
}

A 48-year-old man was admitted to our hospital with 1-month history of petechiae and edema of the bilateral lower extremities, polyarthralgia, gait disturbance, and hematochezia. He also had 2-year history of anorexia and an unbalanced diet that did not include any fresh vegetables or fruits. On examination, his conjunctivae were pale and his hemoglobin was $5.7 \mathrm{~g} / \mathrm{dL}$. He had leukopenia $(2970 / \mu \mathrm{L})$, thrombocytopenia $(620000 / \mu \mathrm{L})$, and hypoalbuminemia $(2.9 \mathrm{~g} / \mathrm{dL})$. The serum vitamin B1 level was $11.0 \mathrm{ng} / \mathrm{mL}$ (24$66 \mathrm{ng} / \mathrm{mL}$ ), the serum vitamin $\mathrm{C}$ level was $<0.2 \mu \mathrm{g} / \mathrm{mL} \quad(5.5-16.8 \mu \mathrm{g} / \mathrm{mL})$, and the serum folate level was $2.8 \mathrm{ng} / \mathrm{mL}$ (3.1-100,000 ng/mL).

Esophagogastroduodenoscopy

(EGD)

showed multiple intramucosal hemorrhages and redness in the fornix ( $\bullet$ Fig. 1 a), the upper gastric body, the antrum ( $\mathrm{Fig.1b}$ ), and the descending portion of the duodenum ( $\bullet$ Fig. 1 c). Colonoscopy showed multiple intramucosal hemorrhages and redness extending from the ascending colon to the rectum ( $\mathbf{F i g} .2$ ) and edema and erosions in the rectum. Histological examination of the biopsy specimens of the rectal lesions revealed fibrin exudation and mild infiltration of inflammatory cells ( Fig.3), consistent with hemorrhagic mucosa. The patient was diagnosed as having scurvy with gastrointestinal bleeding. Vitamin supplementation and adequate nutrition alleviated the symptoms. With the aid of rehabilitation management he was able to walk and was discharged.

Ascorbic acid activates several hydrolases, one of which (prolyl hydroxylase) forms the hydroxyproline that stabilizes the collagen triple-helix structure. Thus, the present patient had probably become susceptible to bleeding from the capillaries because of defective collagen synthesis resulting in fragile capillary walls. Compared with earlier times, scurvy is now seen more rarely, most often occurring in elderly people, alcoholics, institutionalized patients, people on fad diets or those with malabsorption disorder [1]. People with scurvy have submucosal hemor-
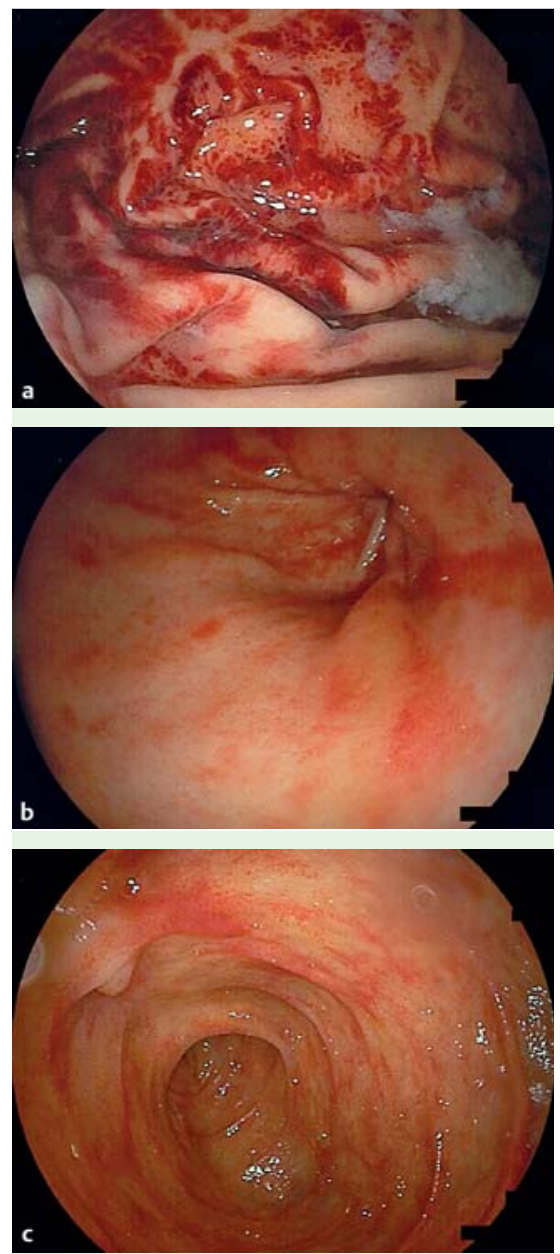

Fig. 1 Esophagogastroduodenoscopy (EGD) findings in a 48-year-old man with petechiae and edema of the bilateral lower extremities, polyarthralgia, gait disturbance, and hematochezia. a Multiple intramucosal hemorrhage and redness in the fornix. $\mathbf{b}$ Linear redness in the antrum. c Multiple intramucosal hemorrhages and redness in the descending portion of the duodenum.

rhages in the stomach, duodenum, and the colon [2-4]. It is important for gastroenterologists to include scurvy in the differential diagnosis of patients presenting with petechiae, polyarthralgia, and gastrointestinal bleeding.

Endoscopy_UCTN_Code_CCL_1AB_2AD_3AZ

Competing interests: None

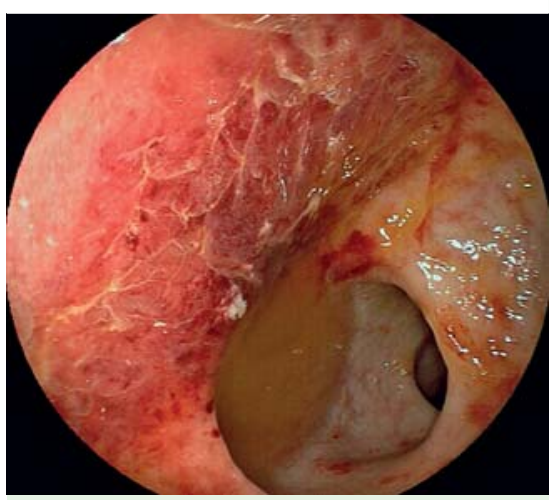

Fig. 2 Colonoscopy showing multiple intramucosal hemorrhage and redness in the rectum.

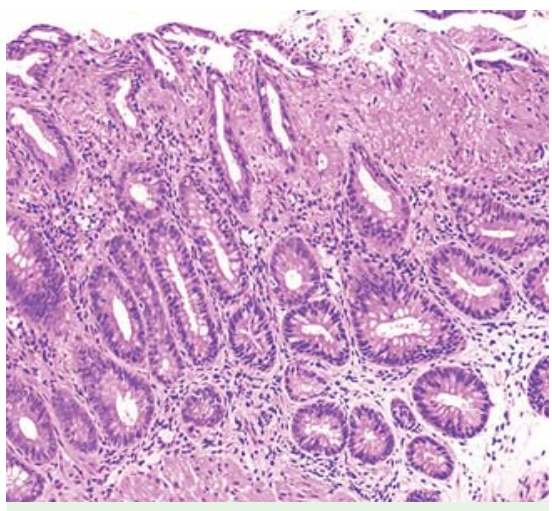

Fig. 3 Histological section of a rectal lesion showing fibrin exudation and mild infiltration of inflammatory cells.

\section{A. Ohta ${ }^{1}$, S. Yoshida ${ }^{1}$, H. Imaeda ${ }^{1}$, H. Ohgo ${ }^{1}$, T. Sujino ${ }^{1}$, M. Yamaoka ${ }^{1}$, R. Kanno ${ }^{1}$, T. Kobayashi ${ }^{1}$, S. Kinoshita ${ }^{1}$, S. lida ${ }^{1}$, K. Inoue ${ }^{1}$, H. Okada ${ }^{1}$, R. Kin², H. Kayano², K. Yamamoto", H. Nakamoto ${ }^{1}$}

${ }^{1}$ Department of General Internal Medicine, Saitama Medical University, Saitama, Japan

${ }^{2}$ Department of Pathology, Saitama Medical University, Saitama, Japan 


\section{References}

1 Pimentel L. Scurvy: historical review and current diagnostic approach. Am J Emerg Med 2003; 21 (Suppl. 04): 328-332

2 Schuman RW, Rahmin M, Dannenberg AJ. Scurvy and the gastrointestinal tract. Gastrointest Endosc 1997; 45: 195-196

3 Canani RB, Frabellanza AG, Giudice ED. Haemorrhagic gastritis in a neurologically impaired boy. Gut 2006; 56: 1511, 1535

4 Berkram P, Bedano PM, Kahi CJ et al. A landlubber with an ancient mariner's leaky vessels. Gastrointest Endosc 2007; 66: 1065 1066

\section{Bibliography}

Dol http://dx.doi.org/

10.1055/s-0032-1326456

Endoscopy 2013; 45: E147-E148

(c) Georg Thieme Verlag KG

Stuttgart · New York

ISSN 0013-726X

\section{Corresponding author}

\section{H. Imaeda}

Department of General Internal Medicine Saitama Medical University

38 Morohongo, Moroyama-machi, Iruma-gun

Saitama

350-0495

Japan

Fax: $+81-49-2761667$

imaedahi@yahoo.co.jp 